\title{
Transactions
}

Cite this: Dalton Trans., 2012, 41, 12984

wWw.rsc.org/dalton

PAPER

\section{Nickel complexes with "click"-derived pyridyl-triazole ligands: weak intermolecular interactions and catalytic ethylene oligomerisation $\uparrow$}

\author{
David Schweinfurth, ${ }^{a, b}$ Cheng-Yong Su, ${ }^{c}$ Shi-Chao Wei, ${ }^{c}$ Pierre Braunstein ${ }^{d}$ and Biprajit Sarkar*a,b
}

Received 7th January 2012, Accepted 30th August 2012

DOI: $10.1039 / \mathrm{c} 2 \mathrm{dt} 31805 \mathrm{a}$

The ligands 1-(cyclohexyl)-4-(2-pyridyl)-1,2,3-triazole (1), 1-(2,6-diisopropylphenyl)-4-(2-pyridyl)1,2,3-triazole (2), 1-(4-butoxyphenyl)-4-(2-pyridyl)-1,2,3-triazole (3) and 1-(methyl)-4-(2-pyridyl)-1,2,3triazole (4) were synthesized by the $\mathrm{Cu}(\mathrm{I})$ catalyzed "Click" reaction between 2-pyridylacetylene and the corresponding azides. The ligands were then reacted with $\mathrm{NiBr}_{2} \cdot 3 \mathrm{H}_{2} \mathrm{O}$ to generate the complexes (1) ${ }_{2} \mathrm{NiBr}_{2}$ (1a), (2) ${ }_{2} \mathrm{NiBr}_{2}$ (2a), (3) ${ }_{2} \mathrm{NiBr}_{2}$ (3a) and (4) $)_{2} \mathrm{NiBr}_{2}$ (4a). Structural characterization of 1a confirmed the mononuclear and distorted octahedral environment around the $\mathrm{Ni}$ (II) center, with the pyridyl-triazole ligands coordinating in a bis-chelating fashion. Bond length analysis inside the 1,2,3-triazole ring shows a short $\mathrm{N}=\mathrm{N}$ double bond that is flanked by two longer $\mathrm{C}-\mathrm{N}$ and $\mathrm{N}-\mathrm{N}$ bonds pointing to the existence of "azo" character in the ring. The highly polar five-membered 1,2,3-triazole ring makes its $\mathrm{C}-\mathrm{H}$ bond acidic, and these bonds participate in an extended weak intermolecular $\mathrm{C}-\mathrm{H} \cdots \mathrm{Br}$ interactions with the $\mathrm{Br}$-groups of neighboring molecules, resulting in a 3-D network. The nickel complexes with these "Click" ligands were tested as pre-catalysts for ethylene oligomerization, and the complexes showed moderate activity in that reaction with good selectivity towards $\mathrm{C} 4$ oligomers.

\section{Introduction}

The Huisgen $[3+2]$ cycloaddition reaction between azides and alkynes was reported in the thermal form decades back. ${ }^{1}$ The $\mathrm{Cu}(\mathrm{I})$ catalyzed version of this reaction has been popularized as the "Click" reaction in recent years (Scheme 1). ${ }^{2,3}$

This reaction works under mild conditions, delivers high product yields of exclusively one isomer, and is tolerant against a host of functional groups. Because of these attractive features, the "Click" reaction has become an important tool in every chemist's synthetic toolbox. ${ }^{4}$ The existence of reasonably basic nitrogen atoms in the 1,2,3-triazole rings, and the possibility of introducing additional donor groups in the substituents, has led to these classes of compounds being used as ligands in coordination chemistry. ${ }^{5}$ Thus a host of metal centers have been coordinated to such "Click" derived ligands, and the metal complexes have found use in electrochemical ${ }^{6-12}$ and photochemical studies, ${ }^{11-16}$ in supramolecular chemistry, ${ }^{17-21}$ magnetism, ${ }^{22,23}$

\footnotetext{
${ }^{a}$ Institut für Anorganische Chemie, Universität Stuttgart,

Pfaffenwaldring 55, D-70550 Stuttgart, Germany

${ }^{b}$ Institut für Chemie und Biochemie, Anorganische Chemie, Freie

Universität Berlin, Fabeckstraße 34-36, D-14195 Berlin, Germany. E-mail: biprajit.sarkar@fu-berlin.de

${ }^{c}$ Lehn Institute of Functional Materials, School of Chemistry and Chemical Engineering, Sun Yat-Sen University, Guangzhou, 510275, China

${ }^{d}$ Laboratoire de Chimie de Coordination, UMR CNRS 7177, Université de Strasbourg, 4 rue Blaise Pascal, F-67081 Strasbourg Cédex, France $\dagger$ Electronic supplementary information (ESI) available: UV-vis spectra of the complexes. CCDC 851805. For ESI and crystallographic data in CIF or other electronic format see DOI: $10.1039 / \mathrm{c} 2 \mathrm{dt} 31805 \mathrm{a}$
}

metal-ion sensing ${ }^{4 a, 24}$ and catalysis. ${ }^{25-30}$ We have recently investigated metal complexes of substituted 1,2,3-triazole ligands for their electrochemical properties, ${ }^{31}$ magnetic bistability ${ }^{32}$ and their application in homogenous catalysis. ${ }^{33,34}$ In this context, substituted pyridyl-triazoles were used in combination with $\mathrm{d}^{8}$ metal centers like $\mathrm{Pd}$ (II) and $\mathrm{Pt}$ (II) by us ${ }^{31,35}$ and others. ${ }^{36-41} \mathrm{In}$ this report we present new complexes $(\mathbf{1})_{2} \mathrm{NiBr}_{2}(\mathbf{1 a}),(\mathbf{2})_{2} \mathrm{NiBr}_{2}$ (2a), (3) ${ }_{2} \mathrm{NiBr}_{2}(\mathbf{3 a})$ and $(\mathbf{4})_{2} \mathrm{NiBr}_{2}$ (4a) that contain the $\mathrm{d}^{8}$ metal center $\mathrm{Ni}$ (II) with the pyridyl-triazoles, 1-(cyclohexyl)-4-(2pyridyl)-1,2,3-triazole (1), 1-(2,6-diisopropylphenyl)-4-(2pyridyl)-1,2,3-triazole (2), 1-(4-butoxyphenyl)-4-(2-pyridyl)1,2,3-triazole (3) and 1-(methyl)-4-(2-pyridyl)-1,2,3-triazole (4). We also describe here the differences in the synthesis and properties of these complexes compared to those of their higher homologues. Structural characterization of one of the complexes is provided. We also present the use of these complexes as pre-catalysts for ethylene oligomerisation. To the best of our knowledge, these are the first metal complexes based on substituted "click" pyridyl-triazole ligands that have been reported as pre-catalysts for ethylene oligomerisation. There have been some recent reports on the use of nickel complexes of triazole substituted $\alpha$-diimine ligands as precatalysts for the polymerization of norbornene and styrene. ${ }^{42,43}$

\section{Results and discussion}

\section{Synthesis and characterization}

The ligands 1-(cyclohexyl)-4-(2-pyridyl)-1,2,3-triazole (1), ${ }^{35}$ 1-(4-butoxyphenyl)-4-(2-pyridyl)-1,2,3-triazole $\quad(3)^{44}$ and 


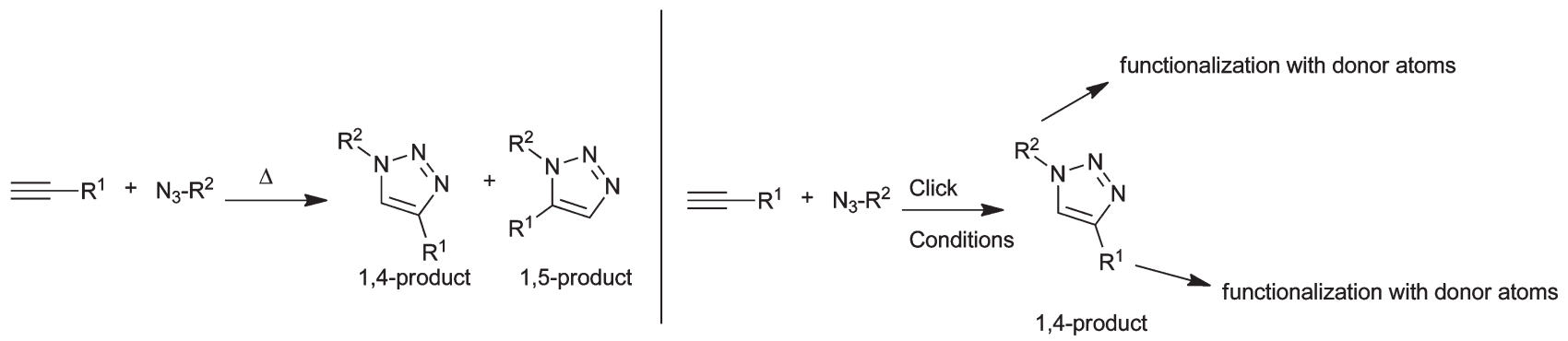

Scheme 1 Thermal cycloaddition reaction between azides and alkynes (left) and the $\mathrm{Cu}(\mathrm{I})$ catalyzed "Click" reaction (right).

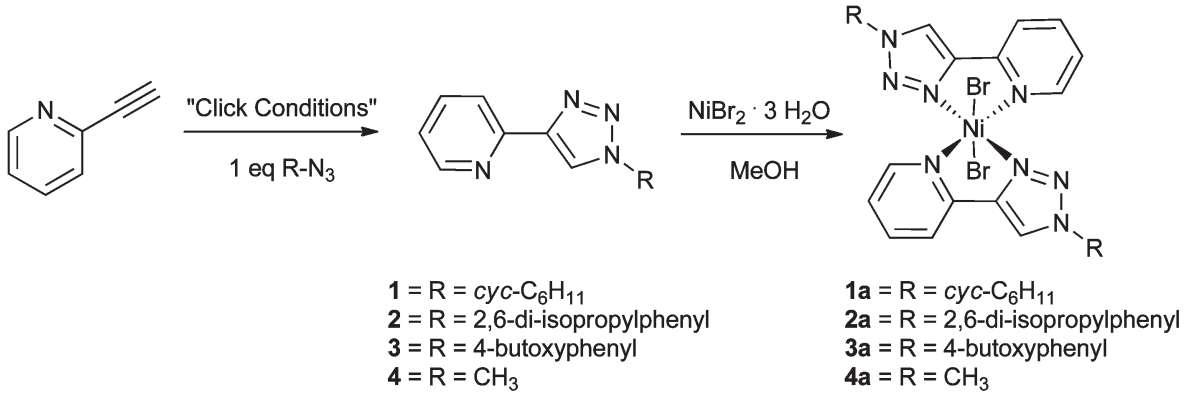

Scheme 2 Synthesis of complexes 1a-4a.

1-(methyl)-4-(2-pyridyl)-1,2,3-triazole $(\mathbf{4})^{45}$ were synthesized according to the reported procedure, and the ligand 1-(2,6-diisopropylphenyl)-4-(2-pyridyl)-1,2,3-triazole (2) was prepared by a click protocol from 2-pyridylacetylene and 2,6-diisopropylphenylazide, using $\mathrm{CuSO}_{4}$ together with ascorbic acid as the catalyst. Additionally, the tripodal ligand tris[(1-benzyl-1H-1,2,3triazol-4-yl)methyl]amine, tbta was used for improving the catalytic activity in that reaction (Experimental section). Reactions of the ligands $1,2,3$ and 4 with $\mathrm{NiBr}_{2} \cdot 3 \mathrm{H}_{2} \mathrm{O}$ afforded the complexes 1a, 2a, 3a and 4a in excellent yields (Scheme 2).

The synthesis of the complexes, which at a first glance looks straightforward, is actually cumbersome. Hence, a careful control of reaction conditions is required to synthesize the "bis" complex. After monitoring a host of conditions, and screening a set of ligands, we were able to determine the ones required to preferentially stabilize the "bis" complex. We were not able to synthesize four coordinated complexes of the form (L) $\mathrm{NiBr}_{2}$, $\mathrm{L}=$ pyridyl-triazole under the tested conditions. For the corresponding Pd(II) and Pt(II) cases, the four coordinated complexes were the exclusively isolated products. ${ }^{31,35}$ This is of course related to the strong tendency of $\operatorname{Pd}($ II) and $\operatorname{Pt}($ II) complexes to stabilize a square planar environment because of the huge gain through ligand field splitting. ${ }^{46}$ The $3 \mathrm{~d}$ metal ion $\mathrm{Ni}(\mathrm{II})$ is capable of adopting a variety of coordination modes depending on the electronic and steric nature of the ligands. In the present case, it was possible to isolate octahedrally coordinated $\mathrm{Ni}$ (II) complexes with two bis-chelating ligands and two additional bromide ligands.

The complexes were characterized by elemental analyses, UV-Vis spectroscopy and mass spectrometry (Experimental section). Mass spectra of the compounds showed peaks at $\mathrm{m} / \mathrm{z}$ corresponding to the di-cations formed by the loss of two bromide ions from the complexes (Experimental section). Ni(II) centers in an octahedral environment are usually characterized by three different $\mathrm{d}-\mathrm{d}$ transitions in the visible or NIR region in their absorption spectroscopy. ${ }^{47}$ These bands which are transitions from the ${ }^{3} \mathrm{~A}_{2 \mathrm{~g}}(\mathrm{~F})$ to ${ }^{3} \mathrm{~T}_{1 \mathrm{~g}}(\mathrm{P}),{ }^{3} \mathrm{~T}_{1 \mathrm{~g}}(\mathrm{~F})$ and ${ }^{3} \mathrm{~T}_{2 \mathrm{~g}}(\mathrm{~F})$ states, respectively, are spin allowed, but parity forbidden, and are hence usually weak in intensity. The solubility of the complexes reported herein is poor in all tested organic solvents. Hence, it was possible to record UV-Vis-NIR spectra of these complexes only with a limited concentration. The recorded spectra for all the complexes are quite similar (Fig. S1 $\dagger$ ). Of the three transitions mentioned above, the one at the lowest wavelength usually is the most intense. For $\mathbf{3 a}$ a band of weak intensity is observed at $370 \mathrm{~nm}$ and this is assigned to a ${ }^{3} \mathrm{~T}_{1 \mathrm{~g}}(\mathrm{P}) \rightarrow{ }^{3} \mathrm{~A}_{2 \mathrm{~g}}(\mathrm{~F})$ transition. For the other complexes a weak shoulder can be seen at around the same region (Fig. S1†). The other two expected $\mathrm{d}-\mathrm{d}$ transitions are not observed in the reported complexes, possibly due to their intrinsic weak nature and the low solubility of the complexes. Low solubility of the complexes precluded a reliable determination of the extinction coefficients. Additionally, all complexes show absorptions in the UV region which are assigned to intra-ligand transitions of the pyridyl-triazole ligands. Such bands are reminiscent of bands observed for the corresponding Pd(II) and Pt(II) complexes with such ligands..$^{31,35}$ Interestingly, the position of these bands in the UV-region seems to correlate with the electronic nature of the substituents on the triazole ring. Thus, for 1a and 4a with alkyl substituents on the triazole ring, this band appears at $275 \mathrm{~nm}$, and for $\mathbf{2 a}$ and $\mathbf{3 a}$ with aryl substituents, the same band appears at $283 \mathrm{~nm}$ (Fig. S1†).

Despite their paramagnetism, which precluded their characterization by NMR spectroscopy, complexes 1a and 2a were EPR 


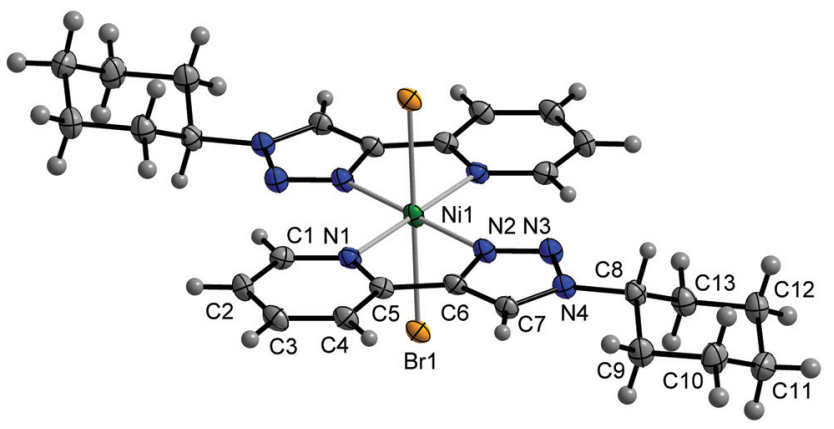

Fig. 1 ORTEP plot of 1a. Ellipsoids are drawn at 50\% probability. Ni1-N1，2.084(2); Ni1-N2, 2.083(2); Ni1-Br1，2.601(1); N2-N3, 1.312(3); N2-C6, 1.363(3); N3-N4, 1.348(3) Å. N1-Ni1-N2(chelate), 79.4(1); N1-Ni1-Br1，90.3(1); N2-Ni1-Br1，90.0(1); N1-Ni1-N2, 100.7(1).

Table 1 Crystallographic details for $\mathbf{1 a}$

\begin{tabular}{ll}
\hline & $\mathbf{1 a}$ \\
\hline Chemical formula & $\mathrm{C}_{52} \mathrm{H}_{64} \mathrm{Br}_{4} \mathrm{~N}_{16} \mathrm{Ni}_{2}$ \\
$M_{\mathrm{r}}$ & 1350.25 \\
Cell setting, space group & Orthorhombic, $P b c a$ \\
Temperature $(\mathrm{K})$ & $150(2)$ \\
$a, b, c(\AA)$ & $13.0158(2), 9.8575(2), 20.8946(5)$ \\
$V\left(\AA^{3}\right)$ & $2680.9(2)$ \\
$Z$ & 2 \\
$D_{\mathrm{x}}\left(\mathrm{mg} \mathrm{m}^{-3}\right)$ & 1.673 \\
Radiation type & $\mathrm{Cu} \mathrm{K \alpha}(\lambda=1.54178 \AA)$ \\
$\mu\left(\mathrm{mm}^{-1}\right)$ & 4.790 \\
Crystal size $(\mathrm{mm})$ & $0.25 \times 0.20 \times 0.18$ \\
Meas., indep. and obsvd refl. & $6634,2115,1919$ \\
$R\left[F^{2}>2 \sigma\left(F^{2}\right)\right], \mathrm{w} R\left(F^{2}\right), S$ & $0.024,0.062,1.018$ \\
No. of parameters & 169 \\
$R_{\text {int }}$ & 0.028 \\
$\theta_{\max }\left({ }^{\circ}\right)$ & 62.60 \\
$\Delta \rho_{\max }, \Delta \rho_{\text {min }}\left(\mathrm{e} \AA^{-3}\right)$ & $0.432,-0.331$ \\
\hline
\end{tabular}

silent down to $110 \mathrm{~K}$ in the X-band. This has to do with the large zero-field splitting usually observed for octahedral $S=1$ nickel(II) centers, which is responsible for shifting their signals outside the range of the normal X-band EPR spectrometer. ${ }^{46}$

\section{Crystal structure of 1a}

1a (Fig. 1) was crystallized by slow evaporation of a methanol solution under ambient conditions. It crystallizes in the orthorhombic Pbca space group. Crystallographic details are given in Table 1. Selected bond lengths and bond angles are provided in the caption of Fig. 1.

The nickel center in $\mathbf{1 a}$ is in a distorted octahedral coordination environment which includes the N3-triazole and pyridyl $\mathrm{N}$ atoms from two different ligands (1) in the equatorial plane. The additional axial positions are taken up by the bromide ions that are then trans to each other. In the equatorial plane the pyridine $\mathrm{N}$ as well as the triazole $\mathrm{N}$ donors from the two 1 ligands are mutually trans to each other. The Ni-N distances of 2.083(2) and 2.084(2) $\AA$ and the Ni-Br distances of 2.601(1) $\AA$ are in the expected range. The angles in the plane containing the two 1 ligands deviate from $90^{\circ}$ because of the chelating nature of the

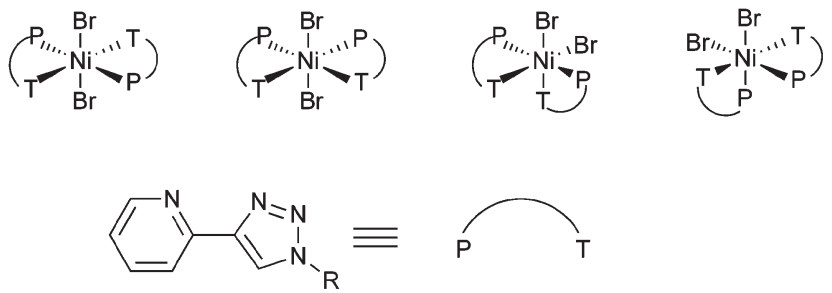

Scheme 3 Possible isomers of an octahedral nickel(II) complex with two substituted pyridyl-triazole ligands (adapted from ref. 49).

ligands 1. The N2-N3 bond length inside the 1,2,3-triazole ring is $1.312(3) \AA$, and the N3-N4 and N2-C6 bond lengths are $1.348(3)$ and 1.363(3) $\AA$, respectively. These distances show a short central $\mathrm{N}-\mathrm{N}$ bond that is flanked by two relatively long $\mathrm{N}-\mathrm{N}$ and $\mathrm{N}-\mathrm{C}$ bonds. Such data point to the $\mathrm{N}=\mathrm{N}$ "azo" character of the central $\mathrm{N}-\mathrm{N}$ bond as opposed to an azine character. Similar observations have been made before by us for the corresponding $\operatorname{Pd}(\mathrm{II})$ and $\mathrm{Pt}(\mathrm{II})$ complexes of pyridyl-triazoles and by others for complexes with other metal centers. ${ }^{31,35,48}$ A similar coordination to that observed here for $\mathbf{1 a}$, was reported for a nickel complex with triazole-substituted $\alpha$-diimine ligands. ${ }^{42}$ In that case the donor atoms from the tetradentate ligands were equatorially coordinated to the nickel centre. The bromide ligands take up the remaining axial sites around the octahedrally coordinated nickel center. In another report, predictions from DFT studies on nickel complexes containing ferrocenyl-substituted pyridyl-triazole ligands showed that among the various isomers that are possible (Scheme 3), the coordination observed here should be most stable. ${ }^{49}$ In the reported compound, the coligands (perchlorates in the reported case and bromide in the present case) are in the axial positions and trans to each other, and the pyridine and triazole nitrogen donor atoms from the two different ligands occupy equatorial sites and are mutually trans to each other. However, no experimental structural evidence was reported for that nickel complex. ${ }^{49}$ We have presented here structural evidence for the stability of this isomer in the solid state.

Due to the presence of three basic nitrogen atoms within a five-membered ring, the $\mathrm{C}-\mathrm{H}$ bond of the 1,2,3-triazole ring is known to be highly acidic. This in turn enormously enhances the ability of these $\mathrm{C}-\mathrm{H}$ bonds to participate in hydrogen bonding. Such targeted hydrogen bonding has been used for anion binding and anion sensing. ${ }^{50}$ In the case of 1a, extensive hydrogen bonding is observed between the bromide ligands that are bound to the nickel centres and the $\mathrm{C}-\mathrm{H}$ group of the 1,2,3-triazole rings of neighboring molecules (Fig. 2). Thus, the $\mathrm{C}-\mathrm{H}$ group of a triazole ring is hydrogen-bonded to the bromide ligand of the next molecule in the same layer. The second bromide ligand forms hydrogen bonds to a $\mathrm{C}-\mathrm{H}$ group on a triazole ring of the next layer. Relevant distances and angles are $\mathrm{C}-$ $\mathrm{H} \cdots \mathrm{Br}=2.676(2) \AA, \mathrm{C}-\mathrm{H}-\mathrm{Br}=169.1(1)^{\circ}$ and $\mathrm{Ni}-\mathrm{Br}-\mathrm{H}=$ $101.4(1)^{\circ}$. In such a way extensive three-dimensional patterns are formed in the solid state. Similar head to tail arrangements stabilized by hydrogen bonding between the acidic $\mathrm{C}-\mathrm{H}$ group of the 1,2,3-triazole ring of one molecule and the $\mathrm{N} 2$ atom of the 1,2,3-triazole ring of an adjacent molecule have been recently observed for Pd(II) complexes with pyridyl-triazole ligands. ${ }^{41}$ 


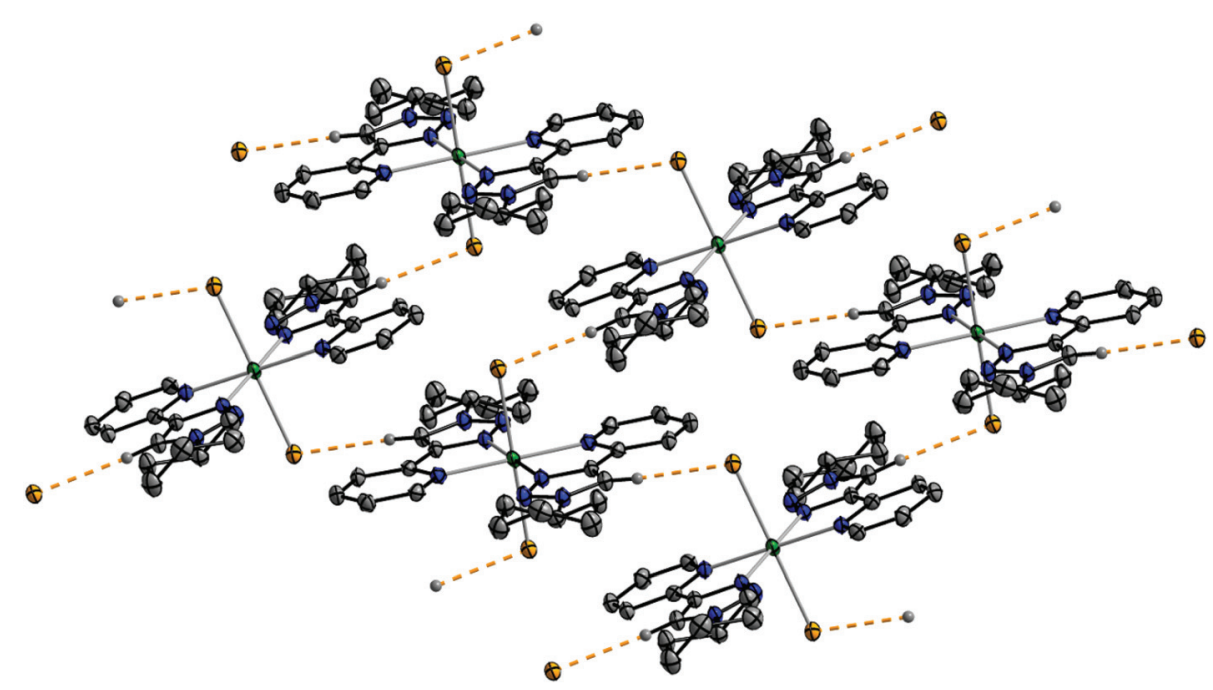

Fig. 2 Intermolecular $\mathrm{C}-\mathrm{H} \cdots \mathrm{Br}$ interactions in $\mathbf{1 a}$ resulting in an extended three dimensional network.

Table 2 Catalytic data for complexes $\mathbf{1 a}-\mathbf{4 a}$ in ethylene oligomerisation with $\mathrm{AlEtCl}_{2}$ as cocatalyst ${ }^{a}$

\begin{tabular}{|c|c|c|c|c|c|c|c|}
\hline \multirow[b]{2}{*}{ Precatalyst } & \multirow[b]{2}{*}{$\mathrm{AlEtCl}_{2}$ (equiv.) } & \multicolumn{3}{|c|}{$\begin{array}{l}\text { Selectivity } \\
(\text { mass } \%)\end{array}$} & \multirow[b]{2}{*}{ Activity $\left[\mathrm{g} \mathrm{C}_{2} \mathrm{H}_{4} /(\mathrm{g} \mathrm{Ni} \cdot \mathrm{h})\right]$} & \multirow[b]{2}{*}{$\mathrm{TOF}\left[\mathrm{mol} \mathrm{C}_{2} \mathrm{H}_{4} /(\mathrm{mol} \mathrm{Ni} \cdot \mathrm{h})\right]$} & \multirow[b]{2}{*}{ Selectivity for 1-butene $(\mathrm{mol} \%)^{b}$} \\
\hline & & $C_{4}$ & $C_{6}$ & $C_{8}$ & & & \\
\hline \multirow[t]{2}{*}{ 1a } & 10 & 71 & 27 & 2 & 8000 & 28900 & 7 \\
\hline & 10 & 77 & 21 & 2 & 8500 & 30600 & 7 \\
\hline \multirow{2}{*}{$2 \mathbf{a}$} & 10 & 73 & 25 & 2 & 11200 & 40200 & 8 \\
\hline & 10 & 71 & 26 & 3 & 12200 & 43800 & 10 \\
\hline $4 a$ & 10 & 66 & 30 & 4 & 14600 & 52600 & 7 \\
\hline & 10 & 63 & 33 & 4 & 15900 & 57300 & 6 \\
\hline
\end{tabular}

${ }^{a}$ Conditions: $T=303 \mathrm{~K}, 10$ bar of $\mathrm{C}_{2} \mathrm{H}_{4}, 35 \mathrm{~min}, 4 \times 10^{-5} \mathrm{~mol}$ of complex; solvent: $10 \mathrm{~mL}$ of toluene (1a and 2a) or chlorobenzene (3a and 4a) for 10 equiv. of $\mathrm{AlEtCl}_{2}\left(5 \mathrm{~mL}\right.$ of $\mathrm{AlEtCl}_{2}$ solution in toluene). ${ }^{b}$ Within the $C_{4}$ fraction.

\section{Catalytic ethylene oligomerisation}

The demand for the production of linear $\alpha$-olefins in the $\mathrm{C}_{4}-\mathrm{C}_{10}$ range is growing fast and this makes the catalytic oligomerisation of ethylene a topic of continuing academic and industrial interest. ${ }^{51-63}$ A range of nickel complexes with chelating ligands have been successfully used as catalysts for this purpose. ${ }^{64}$ However, identifying and controlling the parameters that influence catalytic activity and selectivity still represents a major challenge in this field. Nickel complexes of 1,2,3-triazole-substituted $\alpha$-diimine ligands have recently been used as precatalysts for the polymerization of norbornene and styrene. ${ }^{42,43} \mathrm{We}$ present here results on the first use of nickel complexes of "click" derived pyridyl-triazole ligands in the catalytic oligomerisation of ethylene. Complexes 1a-4a have been tested as precatalysts for this reaction with $\mathrm{AlEtCl}_{2}$ as cocatalyst under 10 bar of ethylene pressure (Experimental section). Initial runs with 1a showed $\mathrm{AlEtCl}_{2}$ to be a better cocatalyst than MAO. Hence all subsequent runs with all the complexes were carried out with $\mathrm{AlEtCl}_{2}$. Toluene turned out to be a better solvent for $\mathbf{1 a}$ and $\mathbf{2 a}$ and chlorobenzene for $\mathbf{3 a}$ and $\mathbf{4 a}$. All the complexes exhibit reasonable activity in the range of about 8000-16000 $\mathrm{g} \mathrm{C}_{2} \mathrm{H}_{4} /$
( $\mathrm{g} \mathrm{Ni} \cdot \mathrm{h}$ ). The selectivity for the $\mathrm{C}_{4}$ fraction was above 70 mass $\%$ for 1a-3a. The complex 1a with the cyclohexyl substituent on the triazole ring shows the lowest activity as well as TOF compared to $\mathbf{2 a - 4 a}$ (see Table 2). The activity and TOF of complexes $\mathbf{2 a}-\mathbf{4 a}$ are comparable, with $\mathbf{4 a}$ containing the least bulky substituent on the 1,2,3-triazole ring, showing the least selectivity of all.

\section{Conclusion}

We have presented here the synthesis of a new pyridyl-triazole ligand, and have used three other literature reported pyridyl-triazole ligands to synthesise their corresponding nickel(II) complexes. Investigation through elemental analyses and mass spectrometry of the complexes confirmed the composition as $\mathrm{NiL}_{2} \mathrm{Br}_{2}, \mathrm{~L}=$ pyridyl-triazole ligand. Structural characterization of one of the complexes showed that the bis-chelating ligands are in the equatorial plane of the octahedron, and the triazole and pyridine nitrogens from each of the ligands are trans to each other. Weak intermolecular $\mathrm{C}-\mathrm{H} \cdots \mathrm{Br}$ interactions are observed in the solid state leading to an ordered three dimensional 
structure. In the UV-Vis spectrum of the complexes only one of the three possible $\mathrm{d}-\mathrm{d}$ transitions was observed. The nickel complexes turned out to be moderately good catalysts for the oligomerisation of ethylene, showing moderate activities and turnover numbers. This report thus presents new examples of nickel(II) complexes with the increasingly popular "Click" based 1,2,3triazole ligands, and shows the utility of metal complexes of these ligands in yet another field of chemistry.

\section{Experimental section}

\section{General}

All solvents were dried and distilled using common techniques unless otherwise mentioned. ${ }^{1} \mathrm{H}-\mathrm{NMR}$ spectra were recorded at 250.13 MHz on a Brucker AC250 instrument. Elemental Analyses was performed on a Perkin Elmer Analyser 240. Mass spectrometry measurements were carried out using an Agilent 6210 ESI-TOF instrument.

\section{Syntheses}

The ligands 1, 3 and $\mathbf{4}$ were prepared according to reported procedures. $^{35,44,45}$

2: 2-Pyridylacetylene (206 mg, $2.0 \mathrm{mmol}$ ), 2,6-diisopropylphenylazide (406 mg, $2.0 \mathrm{mmol}), \mathrm{CuSO}_{4} \cdot 5 \mathrm{H}_{2} \mathrm{O}(25 \mathrm{mg}$, $0.1 \mathrm{mmol})$, sodium ascorbate $(79 \mathrm{mg}, 0.4 \mathrm{mmol}$ ) and TBTA (11 mg, $0.02 \mathrm{mmol}$ ) were dissolved in $\mathrm{CH}_{2} \mathrm{Cl}_{2} / \mathrm{H}_{2} \mathrm{O} /$ tert-BuOH $(2.5 \mathrm{~mL} / 2.5 \mathrm{~mL} / 5 \mathrm{~mL})$ and stirred for $3 \mathrm{~d}$ at $50{ }^{\circ} \mathrm{C}$. Then water $(50 \mathrm{~mL})$ was added and the reaction mixture was extracted with $\mathrm{CH}_{2} \mathrm{Cl}_{2}(3 \times 20 \mathrm{~mL})$. The organic phase was separated and washed with an EDTA/ammonia solution $(1 \mathrm{M})(3 \times 10 \mathrm{~mL})$. Finally the solution was dried over $\mathrm{Na}_{2} \mathrm{SO}_{4}$ and the solvent was evaporated. After flash chromatography over silica $\left(\mathrm{CH}_{2} \mathrm{Cl}_{2}\right.$ : $\mathrm{CH}_{3} \mathrm{OH}$, 99:1) the product was isolated as a white solid (460 mg) in 75\% yields. Anal. Calcd for $\mathrm{C}_{19} \mathrm{H}_{22} \mathrm{~N}_{4}$ : C, 74.48; $\mathrm{H}$, 7.24; N, 18.29; Found C, 74.06; H, 7.37; 18.10. HRMS (ESI) Calcd. for $\mathrm{C}_{19} \mathrm{H}_{23} \mathrm{~N}_{4}\left([\mathrm{M}+\mathrm{H}]^{+}\right): \mathrm{m} / z$ 307.1917; found 307.1915. ${ }^{1} \mathrm{H}-\mathrm{NMR}\left(250 \mathrm{MHz}, \mathrm{CDCl}_{3}\right): \delta 1.15\left(\mathrm{~d},{ }^{3} \mathrm{~J}_{\mathrm{H}-\mathrm{H}}=\right.$ $\left.6.8 \mathrm{~Hz}, 6 \mathrm{H}, \mathrm{CH}_{3}\right) ; 1.17\left(\mathrm{~d},{ }^{3} J_{\mathrm{H}-\mathrm{H}}=6.8 \mathrm{~Hz}, 6 \mathrm{H}, \mathrm{CH}_{3}\right) ; 2.35$ (septet, $\left.{ }^{3} J_{\mathrm{H}-\mathrm{H}}=6.9 \mathrm{~Hz}, 2 \mathrm{H}, \mathrm{CH}\right) ; 7.28\left(\mathrm{t},{ }^{3} J_{\mathrm{H}-\mathrm{H}}=7.5 \mathrm{~Hz}, 1 \mathrm{H}\right.$, pyridyl); $7.32\left(\mathrm{~d},{ }^{3} J_{\mathrm{H}-\mathrm{H}}=7.9 \mathrm{~Hz}, 2 \mathrm{H}\right.$, phenyl $) ; 7.51\left(\mathrm{t},{ }^{3} J_{\mathrm{H}-\mathrm{H}}=\right.$ $7.8 \mathrm{~Hz}, 1 \mathrm{H}$, phenyl); $7.84\left(\mathrm{t},{ }^{3} J_{\mathrm{H}-\mathrm{H}}=7.7 \mathrm{~Hz}, 1 \mathrm{H}\right.$, pyridyl); 8.23 (s, $1 \mathrm{H}, 5$-triazole- $H) ; 8.32\left(\mathrm{~d},{ }^{3} J_{\mathrm{H}-\mathrm{H}}=7.9 \mathrm{~Hz}, 1 \mathrm{H}\right.$, pyridyl); 8.62 (multiplet, $1 \mathrm{H}$, pyridyl). ${ }^{13} \mathrm{C}-\mathrm{NMR}\left(62.5 \mathrm{MHz} \mathrm{CDCl}_{3}\right): \delta 24.2$; $24.4 ; 28.6 ; 120.7 ; 123.2 ; 124.0 ; 125.0 ; 131.0 ; 133.3 ; 137.1$; $146.3 ; 148.3 ; 149.7 ; 150.5$.

1a: $\mathrm{NiBr}_{2} \cdot 3 \mathrm{H}_{2} \mathrm{O}(30 \mathrm{mg} ; 0.11 \mathrm{mmol})$ and 1 (50 mg; $0.22 \mathrm{mmol})$ were dissolved in $\mathrm{MeOH}(20 \mathrm{~mL})$ and refluxed for $1 \mathrm{~h}$. The solvent was evaporated to yield the product as a light blue solid (59 mg) in $80 \%$ yields. Slow evaporation of a methanol solution yielded crystals suitable for X-ray diffraction. Anal. Calcd for $\mathrm{C}_{26} \mathrm{H}_{32} \mathrm{Br}_{2} \mathrm{~N}_{8} \mathrm{Ni}$ : C, 46.26; H, 4.78; N, 16.60; Found $\mathrm{C}, 45.74 ; \mathrm{H}, 4.83 ; 16.33$. UV-Vis $\left(\mathrm{CH}_{2} \mathrm{Cl}_{2}\right)$ : nm 276. HRMS (ESI) Calcd. for $\mathrm{C}_{26} \mathrm{H}_{32} \mathrm{~N}_{8} \mathrm{Ni}\left(\left[\mathrm{M}-2 \mathrm{Br}^{-}\right]^{2+}\right): m / z$ 257.1046; found 257.1047 .

2a: The compound was prepared following the procedure for 1a to yield a light blue solid $(78 \mathrm{mg})$ in $85 \%$ yields. Anal. Calcd for $\mathrm{C}_{38} \mathrm{H}_{44} \mathrm{Br}_{2} \mathrm{~N}_{8} \mathrm{Ni}$ : C, 54.90; H, 5.33; N, 13.48; Found $\mathrm{C}$,
54.91; $\mathrm{H}, 5.36 ; 13.07$. UV-Vis $\left(\mathrm{CH}_{2} \mathrm{Cl}_{2}\right)$ : nm 283. HRMS (ESI) Calcd. for $\mathrm{C}_{38} \mathrm{H}_{44} \mathrm{~N}_{8} \mathrm{Ni}\left(\left[\mathrm{M}-2 \mathrm{Br}^{-}\right]^{2+}\right): \mathrm{m} / z$ 335.1516; found 335.1520 .

3a: The compound was prepared following the procedure for 1 a to yield a white solid (62 mg) in 70\% yield. Anal. Calcd for $\mathrm{C}_{34} \mathrm{H}_{36} \mathrm{Br}_{2} \mathrm{~N}_{8} \mathrm{NiO}_{2}$ : C, 50.59; H, 4.50; N, 13.88; Found $\mathrm{C}$, 50.47; $\mathrm{H}, 4.63 ; 13.69$. UV-Vis $\left(\mathrm{CH}_{2} \mathrm{Cl}_{2}\right)$ : nm 282, 370. HRMS (ESI) Calcd. for $\mathrm{C}_{34} \mathrm{H}_{36} \mathrm{~N}_{8} \mathrm{NiO}_{2}\left(\left[\mathrm{M}-2 \mathrm{Br}^{-}\right]^{2+}\right): m / z$ 323.1152; found 323.1187 .

4a: The compound was prepared following the procedure for 1 a to yield a white solid $(27 \mathrm{mg})$ in $46 \%$ yield. Anal. Calcd for $\mathrm{C}_{16} \mathrm{H}_{16} \mathrm{Br}_{2} \mathrm{~N}_{8} \mathrm{Ni}$ : C, 35.66; H, 2.99; N, 20.79; Found C, 35.25; $\mathrm{H}, 3.15 ; 20.38$. UV-Vis $\left(\mathrm{CH}_{2} \mathrm{Cl}_{2}\right)$ : nm 277. HRMS (ESI) Calcd for $\mathrm{C}_{16} \mathrm{H}_{16} \mathrm{~N}_{8} \mathrm{Ni}\left(\left[\mathrm{M}-2 \mathrm{Br}^{-}\right]^{2+}\right): m / z$ 189.0420; found 189.0432 .

\section{Catalytic oligomerization of ethylene}

The catalytic reactions were performed in a magnetically stirred (1200 rpm) $145 \mathrm{~mL}$ stainless steel autoclave. A $125 \mathrm{~mL}$ glass container was used to avoid corrosion of the autoclave walls. The precatalyst solutions were prepared by dissolving 1a (33.2 $\left.\mathrm{mg}, 4 \times 10^{-5} \mathrm{~mol}\right)$ or $\mathbf{2 a}\left(27 \mathrm{mg}, 4 \times 10^{-5} \mathrm{~mol}\right)$ in toluene $(10 \mathrm{~mL})$, and $\mathbf{3 a}\left(32.3 \mathrm{mg}, 4 \times 10^{-5} \mathrm{~mol}\right)$ or $\mathbf{4 a}(21.5 \mathrm{mg}, 4 \times$ $\left.10^{-5} \mathrm{~mol}\right)$ in chlorobenzene $(10 \mathrm{~mL})$. In all cases, $\mathrm{AlEtCl}_{2}$ was used as cocatalyst $\left(8 \times 10^{-5} \mathrm{mmol}\right.$ in toluene). The solution of the precatalyst was injected into the reactor under an ethylene flux, then $5 \mathrm{~mL}$ of the cocatalyst toluene solution (10 equiv.) was added (total volume: $15 \mathrm{~mL}$ ). All catalytic reactions were started between 20 and $30{ }^{\circ} \mathrm{C}$. No cooling of the reactor was done during the reaction. After injection of the catalyst and cocatalyst solutions under a constant low flow of ethylene, the reactor was pressurized to 10 bars. The temperature increased, due solely to the exothermicity of the reaction. The 10 bars working pressure was maintained through a continuous feed of ethylene from a bottle placed on a balance to allow continuous monitoring of the ethylene uptake. At the end of each test $(35 \mathrm{~min}$, unless otherwise specified) a dry ice bath was used to rapidly cool the reactor. When the inner temperature reached $0{ }^{\circ} \mathrm{C}$, the ice bath was removed, allowing the temperature to slowly rise to $18^{\circ} \mathrm{C}$. The gaseous phase was then transferred into a $10 \mathrm{~L}$ polyethylene tank filled with water. An aliquot of this gaseous phase was transferred into a Schlenk flask, previously evacuated, for GC analysis. The amount of ethylene not consumed was thus determined. Although this method is of limited accuracy, it was used throughout and gave satisfactory reproducibility. The reaction mixture in the reactor was quenched in situ by the addition of ethanol $(10 \mathrm{~mL})$, transferred into a Schlenk flask, and separated from the metal complexes by trap-to-trap evaporation $\left(20{ }^{\circ} \mathrm{C}\right.$, 0.8 mbar) into a second Schlenk flask previously immersed in liquid nitrogen in order to avoid loss of product.

\section{X-ray crystallography}

A suitable single crystal of $\mathbf{1 a}$ was selected and mounted onto a thin glass fiber. X-ray intensity data were measured at $150 \mathrm{~K}$ on an Oxford Gemini $S$ Ultra diffractometer with the Enhance $\mathrm{X}$-ray Source of $\mathrm{Cu}-\mathrm{K} \alpha$ radiation $(\lambda=1.54178 \AA)$ using the $\omega-\varphi$ 
scan technique. ${ }^{65}$ Empirical absorption correction was applied using spherical harmonics implemented in SCALE3 ABSPACK scaling algorithm. ${ }^{66}$ The structure was solved by direct methods and refined by full-matrix least-squares against $F^{2}$ of all data using the SHELXTL program package. ${ }^{67}$ Anisotropical thermal factors were assigned to the non-hydrogen atoms, while the positions of the hydrogen atoms were generated geometrically, assigned isotropic thermal parameters, and allowed to ride on their respective parent atoms before the final cycle of leastsquares refinement. CCDC-851805 contains the supplementary crystallographic data for this paper.

\section{Acknowledgements}

This work was supported by the Baden-Württemberg-Stiftung, CNRS, the Ministère de l'Enseignement et de la Recherche, and the Institut Français du Pétrole, Energies Nouvelles (IFPEN). We thank Marc Mermillon-Fournier and Eric Wagenblast for experimental help. We are extremely grateful to Dr Andreas Springer and the mass spectrometry facility of the Freie Universität Berlin for very efficient and fast measurements.

\section{References}

1 (a) R. Huisgen, R. Knorr, L. Möbius and G. Szeimies, Chem. Ber., 1965, 98, 4014; (b) R. Huisgen, G. Szeimies and L. Möbius, Chem. Ber., 1967, 100, 2492.

2 V. Rostovtsev, L. G. Green, V. V. Fokin and K. B. Sharpless, Angew. Chem., Int. Ed., 2002, 41, 2596.

3 C. V. Tornoe, C. Christensen and M. Meldal, J. Org. Chem., 2002, 67, 3057.

4 (a) Y. H. Lau, P. J. Rutledge, M. Watkinson and M. H. Todd, Chem. Soc. Rev., 2011, 40, 2848; (b) Y. Hua and A. H. Flood, Chem. Soc. Rev., 2010, 39, 1262.

5 (a) H. Struthers, T. L. Mindt and R. Schibli, Dalton Trans., 2010, 39, 675; (b) J. D. Crowley and D. McMorran, ed. J. Kosmrlj, Springer Berlin, Heidelberg, 2012, vol. 28, p. 31; (c) D. Schweinfurth, N. Deibel, F. Weisser and B. Sarkar, Nachr. Chem., 2011, 59, 937; (d) G. Aromi, L. A. Barrios, O. Robeau and P. Gamez, Coord. Chem. Rev., 2011, 255, 485.

6 Y. Li, J. C. Huffman and A. H. Flood, Chem. Commun., 2007, 2692.

7 R. M. Meudtner, M. Ostermeier, R. Goddard, C. Limberg and S. Hecht, Chem.-Eur. J., 2007, 13, 9834.

8 J. T. Fletcher, B. J. Bumgarner, N. D. Engels and D. A. Skoglund, Organometallics, 2008, 27, 5430.

9 W. W. Yang, L. Wang, Y. W. Zhong and J. Yao, Organometallics, 2011, 30, 2236.

10 C. Richardson, C. M. Fitchett, F. R. Keene and P. J. Steel, Dalton Trans., 2008, 2534 .

11 B. Schulze, C. Friebe, M. D. Hager, A. Winter, R. Hoogenboom, H. Goerls and U. S. Schubert, Dalton Trans., 2009, 787.

12 B. Happ, C. Friebe, A. Winter, M. D. Hager, R. Hoogenboom and U. S. Schubert, Chem.-Asian. J., 2009, 4, 154.

13 K. N. Swanick, S. Ladouceur, E. Zysman-Colman and Z. Ding, Chem. Commun., 2012, 48, 3179.

14 D. G. Brown, N. Sanguantrakun, B. Schulze, U. S. Schubert and C. P. Berlinguette, J. Am. Chem. Soc., 2012, 134, 12354.

15 G. F. Manbeck, W. W. Brennessel and R. Eisenberg, Inorg. Chem., 2011, 50, 3431 .

16 M. Mydlak, C. Bizzarri, D. Hartmann, W. Sarfert, G. Schmid and L. D. Cola, Adv. Funct. Mater., 2010, 20, 1812.

17 J. D. Crowley and P. H. Bandeen, Dalton Trans., 2010, 39, 612.

18 S.-Q. Bai, S. Leelasubcharoen, X. Chen, L. L. Koh, J.-L. Juo and T. S. A. Hor, Cryst. Growth Des., 2010, 10, 1715.

19 V. Steinmetz, F. Couty and O. R. P. David, Chem. Commun., 2009, 343.

20 B. Collason, N. L. Paul, Y. L. Mest and O. Reinaud, J. Am. Chem. Soc., 2010, 132, 4393.
21 V. Aucagne, J. Berna, J. D. Crowley, S. M. Goldup, K. D. Hanni, D. A. Leigh, P. J. Lusby, V. E. Ronaldson, A. M. Z. Slawin, A. Viterisi and D. B. Walker, J. Am. Chem. Soc., 2007, 129, 11950.

22 M. Ostermeier, M.-A. Berlin, R. M. Meudtner, S. Demeshko, F. Meyer, C. Limberg and S. Hecht, Chem.-Eur. J., 2010, 16, 10202.

23 P. M. Guha, H. Phan, J. S. Kinyon, W. S. Brotherton, K. Sreenath, J. T. Simmons, Z. Wang, R. J. Clark, N. S. Dalal, M. Shatruk and L. Zhu, Inorg. Chem., 2012, 51, 3465.

24 F. Otón, M. d. C. Gonzalez, A. Espinosa, A. Tárraga and P. Molina, Organometallics, 2012, 31, 2085.

25 S. Gu, H. Xu, N. Zhang and Y. Chen, Chem.-Asian. J., 2010, 5, 1677.

26 X. C. Cambeiro and M. A. Pericas, Adv. Synth. Cat., 2011, 353, 113.

27 R. Lalrempuia, N. D. McDaniel, H. Müller-Bunz, S. Bernhard and M. Albrecht, Angew. Chem., Int. Ed., 2010, 49, 9765.

28 K. J. Kilpin, U. S. D. Paul, A.-L. Lee and J. D. Crowley, Chem. Commun., 2011, 47, 328.

29 R. Saravanakumar, V. Ramkumar and S. Sankararaman, Organometallics, 2011, 30, 1689

30 C. Hua, K. Q. Vuong, M. Bhadbhade and B. A. Messerle, Organometallics, 2012, 31, 1790.

31 D. Schweinfurth, R. Pattacini, S. Strobel and B. Sarkar, Dalton Trans., 2009, 9291.

32 D. Schweinfurth, F. Weisser, D. Bubrin, L. Bogani and B. Sarkar, Inorg. Chem., 2011, 50, 6114.

33 S. Hohloch, C.-Y. Su and B. Sarkar, Eur. J. Inorg. Chem., 2011, 3067.

34 D. Schweinfurth, S. Demeschko, M. M. Khusniyarov, S. Dechert, V. Gurram, M. R. Buchmeiser, F. Meyer and B. Sarkar, Inorg. Chem., 2012, 51, 7592.

35 D. Schweinfurth, S. Strobel and B. Sarkar, Inorg. Chim. Acta, 2011, 374, 253.

36 A. D'Amora, L. Fanfoni, D. Cozzula, N. Guidolin, E. Zangrando, F. Felluga, S. Gladiali, F. Benedetti and B. Milani, Organometallics, 2010, 29, 4472.

37 K. J. Kiplin and J. D. Crowley, Polyhedron, 2010, 29, 3111.

38 D. Urankar, A. Pevec, I. Turel and J. Kosmrlj, Cryst. Growth Des., 2010, 10, 4920.

39 D. Urankar, P. Pinter, A. Pevec, F. D. Proft, L. Turel and J. Kosmrlj, Inorg. Chem., 2010, 49, 4820.

40 D. Urankar, A. Pevec and J. Kosmrlj, Eur. J. Inorg. Chem., 2011, 1921.

41 K. J. Kilpin, E. L. Gavey, C. J. McAdam, C. B. Anderson, S. J. Lind, C. C. Keep, K. C. Gordon and J. D. Crowley, Inorg. Chem., 2011, 50, 6334.

42 L. Li, C. S. B. Gomes, P. T. Gomes, M. T. Duarte and Z. Fan, Dalton Trans., 2011, 40, 3365.

43 L. Li, P. T. Gomes, M. A. N. D. A. Lemos, F. Lemos and Z. Fan, Macromol. Chem. Phys., 2011, 212, 367.

44 D. Schweinfurth, K. I. Hardcastle and U. H. F. Bunz, Chem. Commun., 2008, 2203.

45 L. Bernet, R. Lalrempuia, W. Ghattas, H. Müller-Bunz, L. Vigara, A. Llobet and M. Albrecht, Chem. Commun., 2011, 47, 8058.

46 J. S. Gispert, Coordination Chemistry, Wiley-VCH Verlag GmbH \& Co., Weinheim, 2008.

47 E. Gonzalez, A. Rodrigue-Witchel and C. Reber, Coord. Chem. Rev., $2007,251,351$.

48 M. Obata, A. Kitamura, A. Mori, C. Kameyama, J. A. Czaplewska, R. Tanaka, I. Kinoshita, T. Kusumoto, H. Hashimoto, M. Harada, Y. Mikita, T. Funabiki and S. Yano, Dalton Trans., 2008, 3292.

49 T. Romero, R. A. Orenes, A. Espinosa, A. Tarraga and P. Molina, Inorg. Chem., 2011, 50, 8214

50 Y. Hua and A. H. Flood, Chem. Soc. Rev., 2010, 39, 1262.

51 B. L. Small and M. Brookhart, J. Am. Chem. Soc., 1998, 120, 7143.

52 G. J. P. Britovsek, V. C. Gibson, B. S. Kimberley, P. J. Maddox, S. J. McTavish, G. A. Sloan, A. J. P. White and D. J. Williams, Chem. Commun., 1998, 849.

53 G. J. P. Britovsek, V. C. Gibson and D. F. Wass, Angew. Chem., Int. Ed., 1999, 38, 428.

54 V. C. Gibson and S. K. Spitzmesser, Chem. Rev., 2003, 103, 283.

55 G. J. P. Britovsek, S. Mastroianni, G. A. Sloan, S. P. D. Baugh, C. Redshaw, V. C. Gibson, A. J. P. White, D. J. Williams and M. R. J. Elsegood, Chem.-Eur. J., 2000, 6, 2221.

56 C. Bianchini, G. Giambastiani, I. G. Rios, G. Mantovani, A. Meli and A. M. Segarra, Coord. Chem. Rev., 2006, 250, 1391.

57 V. C. Gibson, C. Redshaw and G. A. Sloan, Chem. Rev., 2007, 107, 1745 .

58 W.-H. Sun, S. Zhang and W. Zuo, C. R. Chim., 2008, 11, 307. 
59 C. Bianchini, G. Giambastiani, L. Luconi and A. Meli, Coord. Chem. Rev., 2010, 254, 431.

60 A. Boudier, P.-A. R. Breuil, L. Magna, C. Rangheard, J. Ponthus, H. Olivier-Bourbigou and P. Braunstein, Organometallics, 2011, 30, 2640.

61 S. Liu, R. Pattacini and P. Braunstein, Organometallics, 2011, 30, 3549.

62 T. Agapie, Coord. Chem. Rev., 2011, 255, 861.
63 T. Xiao, W. Zhang, J. Lai and W.-H. Sun, C. R. Chim., 2011, 14, 851, and references therein.

64 F. Speiser, P. Braunstein and L. Saussine, Acc. Chem. Res., 2005, 38, 784, and references therein.

65 CrysAlis CCD, Oxford Diffraction, Ltd., Version 1.171.31.7.

66 CrysAlis RED, Oxford Diffraction, Ltd., Version 1.171.31.7.

67 SHELXTL, version 5. 10, Bruker Analytical X-ray Systems, Madison, WI, 1998. 